\title{
Knowledge about chronic total coronary artery occlusions among Polish physicians
}

Poziom wiedzy o przewlekłych okluzjach tętnic wieńcowych wśród polskich lekarzy

\author{
Leszek Bryniarski', Michał Zabojszcz'2, Krzysztof Bryniarski ${ }^{3}$, Michał Terlecki ${ }^{1}$ \\ 1I Klinika Kardiologii i Nadciśnienia Tętniczego, Instytut Kardiologii, Uniwersytet Jagielloński Collegium Medicum, Kraków \\ 2 Oddział Kardiologii, Szpital Specjalistyczny im J. Dietla, Kraków \\ 3 Studenckie Koło Naukowe przy III Katedrze i Oddziale Klinicznym Kardiologii, Śląski Uniwersytet Medyczny, Zabrze
}

Post Kardiol Interw 2010; 6, 2 (20): 66-70

DOI: $10.5114 /$ pwki.2010.14166

\section{Abstract}

Background: Chronic total occlusions (CTO) are diagnosed in about 30\% of angiograms in patients with coronary artery disease. In recent years the efficacy of percutaneous revascularisation of CTO has been on rise but simultaneously has constituted increasingly smaller percentage of all coronary interventions. One of the causes discouraging from such technically demanding procedures may be the lack of knowledge of CTO.

Aim: An attempt to assess the state of knowledge of coronary CTO among Polish physicians.

Methods: In the study participated physicians with an interest in the subject of CTO. Study was performed with a questionnaire including questions regarding basic knowledge of coronary CTO.

Results: In the study participated 115 physicians, most of them were non-invasive cardiologists. Only $36.5 \%$ of responders could provide incidence of CTO correctly. $62.5 \%$ of responders chose medical therapy as a preferable method of treatment. A majority of participants (77.4\%) appreciated the need to demonstrate ischaemia and myocardial viability in the region supplied by the occluded artery before revascularisation of a CTO.

Conclusions: The level of knowledge about coronary CTO among Polish physicians is not sufficient. Further education in this subject is necessary not only among interventional cardiologist but also among other doctors providing care for patients with coronary artery disease.

Key words: chronic total occlusions, percutaneous interventions, physician's knowledge

\section{Streszczenie}

Wstęp: Przewlekłe okluzje tętnic (СTO) stwierdza się w ok. 30\% angiogramów pacjentów z chorobą niedokrwienną serca. W ostatnich latach skuteczność zabiegów przezskórnej rewaskularyzacji CTO wzrasta, ale jednocześnie udrożnienia CTO stanowią coraz niższy odsetek wszystkich interwencji wieńcowych. Jednym z czynników zniechęcających do podejmowania tych wymagających technicznie zabiegów może być brak wiedzy na temat CTO.

Cel: Próba określenia stanu wiedzy na temat przewlekłych okluzji tętnic wieńcowych wśród polskich lekarzy.

Metody: W badaniu wzięli udział lekarze zainteresowani zagadnieniami przewlekłych okluzji tętnic wieńcowych. Zostało ono przeprowadzone przy użyciu ankiety zawierającej pytania dotyczące podstawowych informacji na temat przewlekłych okluzji tętnic wieńcowych.

Wyniki: W badaniu wzięło udział 115 osób, w większości kardiolodzy nieinwazyjni. Jedynie 36,5\% uczestników badania potrafito prawidłowo określić częstość występowania CTO. W 62,5\% respondenci jako preferowaną formę terapii wskazali leczenie zachowawcze. Większość uczestników badania $(77,4 \%)$ dostrzega konieczność wykazania niedokrwienia i żywotności mięśnia sercowego zaopatrywanego przez zamknięte naczynie przed rewaskularyzacją przewlekłej niedrożności tętnicy wieńcowej.

Wnioski: Poziom wiedzy na temat CTO wśród polskich lekarzy jest niewystarczający. Konieczne są dalsze działania edukacyjne w tym zakresie skierowane nie tylko do kardiologów interwencyjnych, ale też pozostałych lekarzy zajmujących się pacjentami z chorobą wieńcową.

Słowa kluczowe: przewlekłe okluzje tętnic, przezskórne interwencje wieńcowe, wiedza lekarzy

\section{Adres do korespondencji/Corresponding author:}

Leszek Bryniarski MD, PhD, I Klinika Kardiologii i Nadciśnienia Tętniczego, Instytut Kardiologii, Uniwersytet Jagielloński Collegium Medicum, ul. Kopernika 17, 31-501 Kraków, tel.: +48 1242473 00, e-mail: __bryniarski@poczta.fm

Praca wptynęła 2.03.2010, przyjęta do druku 14.04.2010. 


\section{Introduction}

Chronic total occlusions (CTO) of the coronary arteries currently characterised by complete discontinuation of the coronary lumen in angiography for more than 3 months are diagnosed in about $30 \%$ of the angiograms in patients with coronary artery disease. CTO revascularisations constitute $5-15 \%$ of the procedures carried out in cathlabs and even $10-20 \%$ of all percutaneous coronary interventions $(\mathrm{PCl})$ in specialised centres [1]. Diagnosis of chronically occluded artery had been a contraindication for percutaneous coronary intervention for many years. For the first time a revascularisation of CTO was described in 1982 [2, 3]. Quarter of century later despite a huge technical progress revascularisation of chronic total occlusions of coronary arteries remains one of the last barrier to overcome in interventional cardiology.

In recent years the use of modern devices and new techniques has improved the efficacy of revascularization procedures of CTO which has reached up to $90 \%$ in the specialised centres [4]. On the other hand in the European countries and in USA revascularisations of CTO constitute increasingly smaller percentage of all $\mathrm{PCI}$ procedures $[1,5]$. The main reason for this tendency is the lack of adequate experience among operators. The revascularisation procedures are highly demanding technically and the efforts of some operators to develop more aggressive programs of CTO revascularisation can remain unspotted among the majority of operators with less enthusiastic approach towards performing these difficult and time consuming procedures $[5,6]$. Among furthers obstacles discouraging from carrying out these procedures the fear of complications, excessive use of contrast agent, excessive radiation dose during the procedure, high device usage and subsequent economic problems as well as a lack of knowledge about CTO can all be mentioned.

\section{Material and methods}

The aim of the study was an attempt to assess the knowledge of chronic coronary artery occlusions among Polish physicians.

In the study participated cardiologists and other specialist with an interest in chronic total occlusions of coronary arteries. The study was carried out with a questionnaire containing 5 questions. All questions were multiple choice questions with 2-7 options among which only one could be chosen. Two first questions characterised the participants, further three referred to the basic knowledge of chronic coronary artery occlusions: the incidence of CTO, preferable method of treatment and the need to assess ischaemia and viability prior to revascularisation.

The study was carried out during the XIII International Congress of Polish Cardiac Society which took place in Poznan from 24 to 26 September 2009. The first Polish monography of chronic occlusions had its premiere there. To receive the book a short questionnaire about chronic coronary artery occlusions had to be completed.

The comparison of numbers and percentages of cases with regards to the whole analysed group is presented. To assess the differences in the nominal variables nonparametric chi-square $\left(\chi^{2}\right)$ Pearson's test, Yates' chi square test $\left(\chi^{2}\right)$ or Fisher's exact test were applied (depending on the number of subjects in subgroups). In order to assess the strength of the relations between variables Spearman's correlation test was used. Results with $p$ value of $<0.05$ were consider significant. Statistical analysis was carried out with a use of STATISTICA 8 PL software (StatSoft Inc.).

\section{Results}

In the study participated 115 responders by completing the questionnaire. The majority of them were non-invasive cardiologists (39.1\%) and internal medicine specialists (32.2\%), subsequently interventional cardiologist (12.2\%), other specialist doctors and medical students (16.5\% in total).

Responders worked in cardiac wards (38.8\%), cardiology departments (15.7\%), medical wards (14.8\%), outpatient departments and cardiology clinics (13.9\% in total). Only $4.3 \%$ of responders indicated cathlab as a main workplace. Only $36.5 \%$ of participants provided a correct incidence of CTO. Most of the responders provided medical therapy as a preferable method of treatment. Detailed answers with regards to the incidence of CTO and the preferable therapy are showed in figures 1 and 2 .

The majority of participants (77.4\%) claimed that it is necessary to assess ischaemia and myocardial viability in the region supplied by the occluded artery prior to revascularisation of the CTO. The detailed distribution of the answers depending on the doctors' speciality is showed in figure 3.

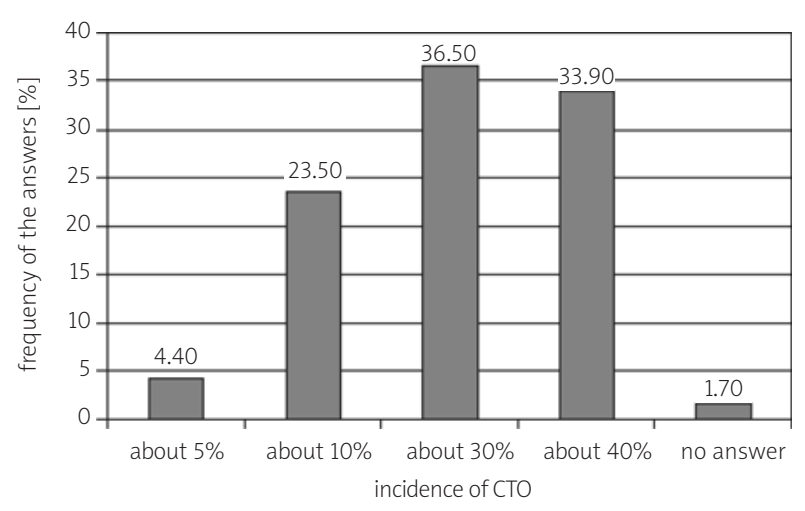

Fig. 1. Incidence of CTO in the view of study responders

Ryc. 1. Częstość występowania CTO w opinii uczestników badania 


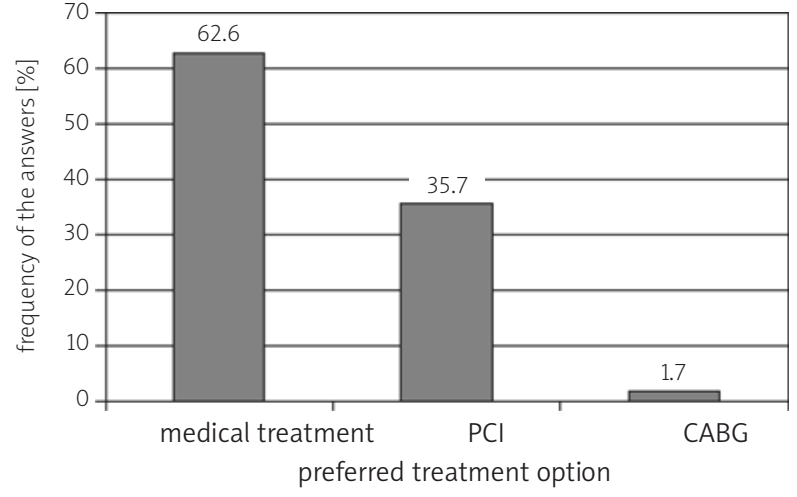

Fig. 2. Preferred treatment option in isolated CTO with well established collateral circulation

Ryc. 2. Preferowana forma leczenia CTO z dobrze rozwiniętym krążeniem obocznym jako jedynej zmiany miażdżycowej tętnic wieńcowych
A correlation was noted between the workplace and the preferable method of СTO treating $(r=0.2037$, $p=0.029$ ).

Percutaneous coronary angioplasty was preferred only by the doctors indicating cathlab as a main workplace. In all other groups medical therapy was more commonly chosen as a preferable treatment method (fig. 4).

There was no relation between the workplace or speciality and the knowledge whether the assessment of ischaemia and viability was necessary before CTO revascularisation. However, there was a correlation between the CTO treatment methods preferences (medical, CTO or CABG) and the view on the need to asses ischaemia and viability prior to revascularisation $(r=0.2716, p=0.003)$. The most commonly the need to assess ischaemia and viability was chosen by doctors preferring $\mathrm{PCl}$ as a method of treatment (fig. 5). interventional cardiologists

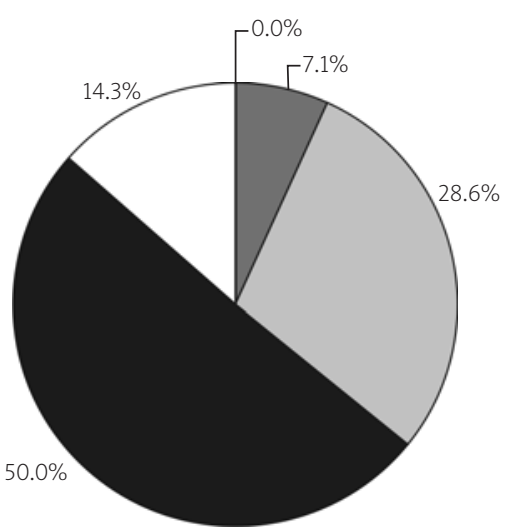

internal medicine specialists

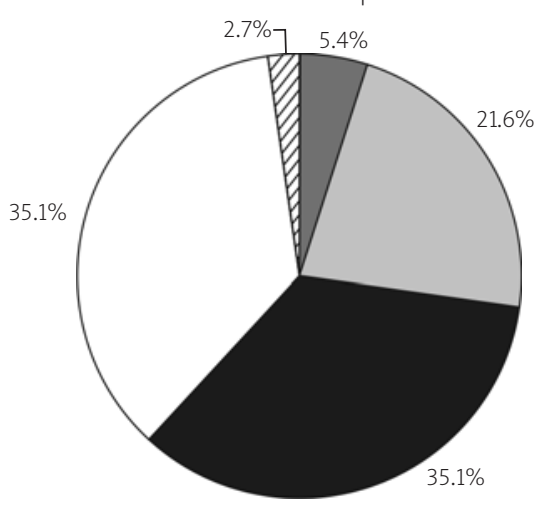

non-invasive cardiologists

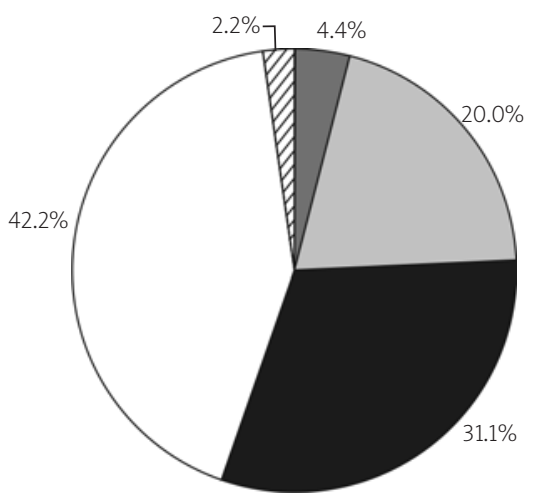

others

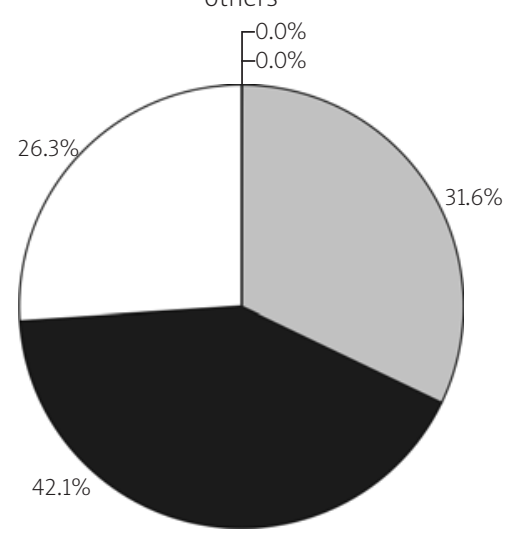

口about 5\%

about $30 \%$

no answer

about 10\% a about 50\%

Fig. 3. Incidence of CTO in the view of study responders depending on their specialty

Ryc. 3. Częstość występowania CTO w opinii uczestników badania w zależności od specjalności lekarzy 


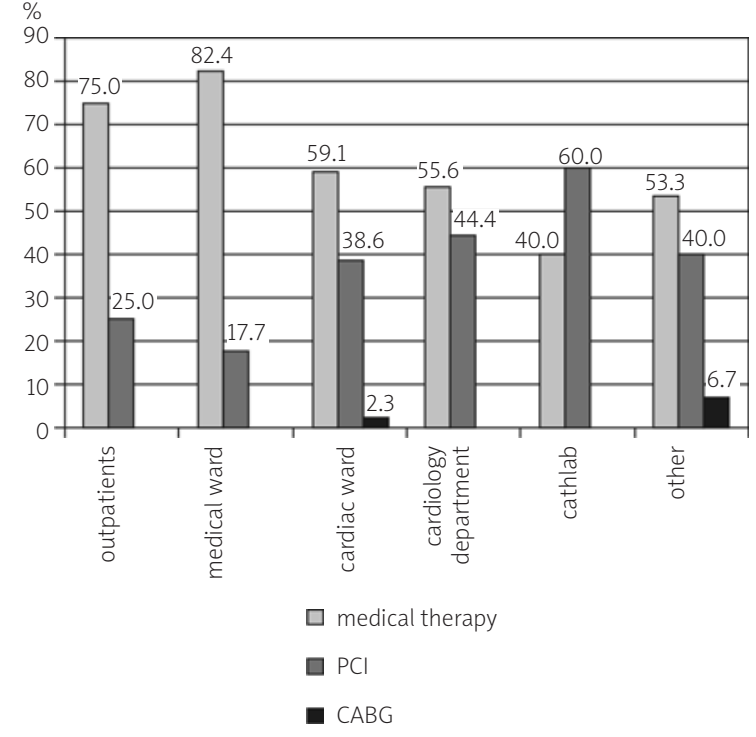

Fig. 4. Preferred CTO treatment option with regards to the workplace

Ryc. 4. Preferowany sposób leczenia CTO w zależności od miejsca pracy

\section{Discussion}

The study presented is the first attempt to assess the knowledge of chronic total occlusions of the coronary arteries among Polish physicians with an interest in cardiology. Obviously, due to the sampling methods the results are not representative. Taking into consideration that the study was carried out during the promotion of the monography of CTO taking place during the Congress of Polish Cardiac Society it can be presumed that study group included responders with an interest in chronic total occlusions. Our report demonstrates the state of knowledge on CTO among doctors who do not perform PCI procedures: non-invasive cardiologists and internal medicine specialists working in hospital wards. Their view on СTO is based on the observations of the management of chronic occlusions in the cooperating centres of interventional cardiology.

An occlusion of one or more coronary arteries is present in about $30 \%$ of angiograms in patients with coronary artery disease. The correct incidence of CTO was chosen by one third of responders. The higher and the lower than real incidence of CTO was indicated with comparable frequencies. It should be noticed that among doctors who claimed cathlab as a main workplace only $50 \%$ of participants correctly estimated the scale of disease.

The majority of responders chose medical therapy as a preferable method of the treatment of CTO. On the basis of available evidence it is known that even in case of well developed collateral circulation patients significantly benefit from revascularisation of СTO especially if the complete revascularisation is possible.

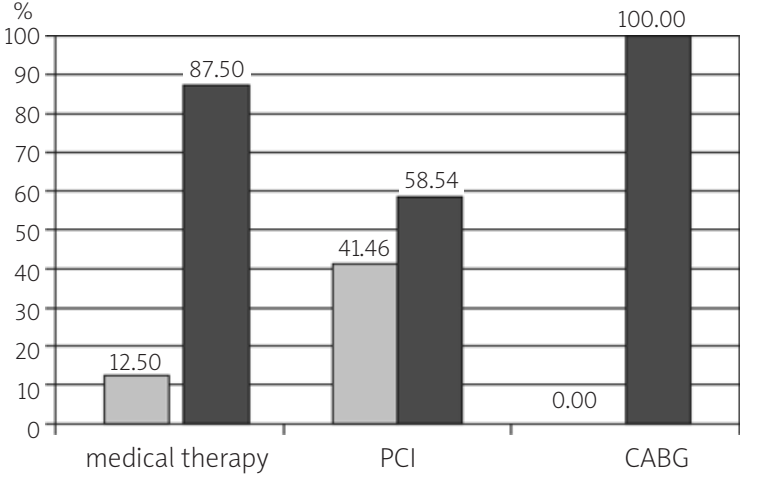

$\square$ no need for additional test if CTO morphology is favourable
$\square$ proof of ischaemia and viability is essential

Fig. 5. Knowledge about the need to assess ischaemia and viability prior to revascularisation with regards to the preferred CTO treatment option Ryc. 5. Wiedza na temat konieczności określenia niedokrwienia i żywotności przed rewaskularyzacja w zależności od preferowanego sposobu leczenia CTO

It is established that CTO with well developed collateral circulation corresponds with a $90 \%$ stenosis of coronary artery. In the majority of patients even very well developed collateral circulation does not provide sufficient functional blood supply of left ventricle but only a minimal supply with nutritional substrates for hibernating myocardium. During dobutamine stress test in less than $10 \%$ of those patients an appropriate functional blood reserve is observed. Well established collateral circulation does not prevent ischaemia and its presence cannot justify refraining form CTO revascularisation procedures [7, 8].

In patients with stable angina in whom chronic total occlusion is diagnosed the one year mortality is almost twofold higher than in patients without CTO (5.5 and 3.1\% respectively) [9]. In the group of patients with myocardial infarction the presence of chronic occlusion of other than culprit coronary artery is the strongest factor influencing the risk of death from cardiovascular causes (three-fold increase) [10]. A successful recanalisation of chronic total occlusion reduces ischaemia, resolves angina, improves left ventricular function, reduces the incidence of ventricular arrhythmia and, the most importantly, influences patients prognosis. 10-years survival after successful angioplasty of CTO is significantly longer than in patients with failed CTO revascularisation procedure (74 vs. $65 \%, p<0.001$ ) [11]. A successful angioplasty of CTO does not only reduce the number of cardiosurgical procedures but also leads to significant reduction of the risk of death in long term follow up [12]. The beneficial effects of $\mathrm{PCl}$ procedure obviously refers only to patients in whom restenosis did not occur. Therefore introduction of drug eluting stents (DES) turned out to be extremely important for the improvement in the 
prognosis of patients undergoing revascularisation procedures for CTO [13].

Clearly, the benefits mentioned above refer only to patients with viable myocardium within the region supplied by the occluded artery and therefore it is necessary to prove ischaemia or viability of myocardium prior to referral for revascularisation. The absence of the pathologic $\mathrm{Q}$ wave in a resting electrocardiogram indicates with a high probability preserved viability of myocardium and is the best prognostic factor of the restoration of left ventricle function after $\mathrm{PCl}$ procedure. Among more advance methods electrocardiographic and imaging stress tests are of the highest importance in an everyday practice. Contractility improvement seen in dobutamine echocardiography indicates the viability of certain myocardial segments and a biphasic response predicts restoration of left ventricular function. The viability of myocardium can be also assessed by means of magnetic resonance and positron emission tomography (PET) but the main limitation is still insufficient availability of those imaging techniques $[14,15]$.

\section{Conclusions}

The results presented indicate that the level of knowledge regarding chronic occlusions among Polish physicians is not sufficient. There is a need for further education in the subject aimed not only at the interventional cardiologists but also at the other doctors treating patients with coronary artery disease.

\section{References}

1. Di Mario C, Werner GS, Sianos G, et al. European perspective in the recanalisation of Chronic Total Occlusions (CTO): consensus document from the EuroCTO Club. Eurolntervention 2007; 3: 30-43.

2. Heyndrickx GR, Serruys PW, van den Brand M, et al. Transluminal angioplasty after mechanical recanalization in patients with chronic occlusion of coronary artery. Circulation 1982; 66 (Suppl. II): II-5.

3. Savage R, Hollman J, Gruentzig A, et al. Can percutaneous transluminal coronary angioplasty be performed in patients with total occlusions? Circulation 1982; 66 (Suppl. II): II-330.

4. Rathore S, Matsuo H, Terashima M, et al. Procedural and inhospital outcomes after percutaneous coronary intervention for chronic total occlusions of coronary arteries 2002 to 2008: impact of novel guidewire techniques. JACC Cardiovasc Interv 2009; 2: 489-497.

5. Grantham JA, Marso SP, Spertus J, et al. Chronic total occlusion angioplasty in the United States. JACC Cardiovasc Interv 2009; 2: 479-486.

6. Lombardi W, Jones N. Coronary CTO intervention. Cardiac Interv Today 2007; 1: 54-56.

7. Werner GS, Surber R, Ferrari M, et al. The functional reserve of collaterals supplying long-term chronic total coronary occlusions in patients without prior myocardial infarction. Eur Heart J 2006; 27: 2406-2412

8. Werner GS. Wskazania do udrożnienia przewlekle zamkniętych tętnic wieńcowych. In: Interwencyjne leczenie przewlekłych niedrożności tętnic. Bryniarski L, Dudek D (eds.). Exemplum, Poznań 2009.

9. Werner GS, Gitt AK, Zeymer U, et al. Chronic total coronary occlusions in patients with stable angina pectoris: impact on therapy and outcome in present day clinical practice. Clin Res Cardiol 2009; 98: 435-441.

10. van der Schaaf RJ, Vis MM, Sjauw KD, et al. Impact of multivessel coronary disease on long-term mortality in patients with STelevation myocardial infarction is due to the presence of a chronic total occlusion. Am J Cardiol 2006; 98: 1165-1169.

11. Suero JA, Marso SP, Jones PG, et al. Procedural outcomes and longterm survival among patients undergoing percutaneous coronary intervention of a chronic total occlusion in native coronary arteries: a 20-year experience. J Am Coll Cardiol 2001; 38: 409-414.

12. Ramanathan K, Gao M, Nogareda GJ, et al. Successful percutaneous recanalization of a non-acute occluded coronary artery predicts clinical outcomes and survival. Circulation 2001; 104: II-415.

13. Hoye A, Tanabe K, Lemos PA, et al. Significant reduction in restenosis after the use of sirolimus-eluting stents in the treatment of chronic total occlusions. J Am Coll Cardiol 2004; 43: 1954-1958

14. Przewłocki T, Surowiec S. Nieinwazyjne metody w ocenie wskazań i skuteczności zabiegów udrażniania tętnic wieńcowych. In: Interwencyjne leczenie przewlekłych niedrożności tętnic. Bryniarski L, Dudek D (eds.). Exemplum, Poznań 2009.

15. Surber R, Schwarz G, Figulla HR, Werner GS. Resting 12-lead electrocardiogram as a reliable predictor of functional recovery after recanalization of chronic total coronary occlusions. Clin Cardiol 2005; 28: 293-297. 